\title{
Geographical distribution of torture: An epidemiological study of torture reported by asylum applicants examined at the Department of Forensic Medicine, University of Copenhagen
}

\author{
J. Busch, MD*, S.H. Hansen, MD*, H.P. Hougen, MD, PhD, DMSc, MPA*
}

\begin{abstract}
Using reports from 154 examinations of alleged torture victims among asylum applicants to Denmark conducted by the Department of Forensic Medicine, University of Copenhagen, between 2001 and 2013, we have categorized the victims into four geographical regions, as well as according to the conflict that caused them to flee. The torture incidents described by the victims were divided into 12 different categories defined by the Istanbul Protocol. These data were cross referenced in order to identify any differences in the prevalence of the 12 forms of torture. The study showed that crush injuries were only reported by refugees from Asia, including Afghanistan and Pakistan, and that incidents of electrical torture were reported twice as frequently by torture victims from Middle Eastern and North African countries, though it was lower among Iraqis, Iranians and ethnic Kurds. Sexual torture was reported by $78 \%$ of females and $25 \%$ of males.
\end{abstract}

\footnotetext{
^) Section of Forensic Pathology at the University of Copenhagen

Correspondence to: johsbusch@gmail.com
}

Keywords: torture, epidemiology, medical history taking, refugees, human rights, Istanbul Protocol

\section{Introduction}

The definition of torture given by the United Nation's Convention against Torture and Other Cruel, Inhuman and Degrading Treatment or Punishment (UNCAT) is also used in the introduction to the Istanbul Protocol:

“... any act by which severe pain or suffering, whether physical or mental, is intentionally inflicted on a person for such purposes as obtaining from him or a third person information or a confession, punishing him for an act which he or a third person has committed, or intimidating or coercing him or a third person, or for any reason based on discrimination of any kind, when such pain or suffering is inflicted by or at the instigation of a public official or other person acting in an official capacity. It does not include pain or suffering arising only from, inherent in or incidental to lawful sanctions." 1

In the period from 2002 to 2012 , the number of asylum applications to Denmark varied between approximately 2,000 and 
6,000 each year. ${ }^{2}$ Identifying how many applicants have experienced torture is difficult. However, a study of randomly selected applicants in the Danish Center Sandholm Refugee Camp, where all asylum applicants are registered, aside from unaccompanied children under 18 , found that the prevalence may be as high as $45 \% .^{3}$

During the application process, if the Danish Immigration Service believes an applicant may have been tortured they can request that the individual be examined and interviewed by the Department of Forensic Medicine at the University of Copenhagen, Aarhus or Southern Denmark. This allows them to document both the victim's account of the alleged abuse in their country of origin, as well as any sequelae. This study details the different alleged forms of torture documented in the period from 2001 to 2013.

Knowing which torture methods are practiced in any given part of the world can be greatly beneficial when examining a possible torture victim, as while some forms of torture leave obvious signs others can be difficult to document. ${ }^{1,3-6}$ The Istanbul Protocol specifically states in Chapter IV, Section A, article 122 that any medical examiner of torture should be prepared to both "correlate the degree of consistency between examination findings and specific allegations of abuse by the patient;" and "correlate the degree of consistency between individual examination findings with the knowledge of torture methods used in a particular region and their common aftereffects;" 1

In many cases torturers deliberately try to avoid leaving any visible traces of the torture they inflict. ${ }^{7-9}$ It is not unreasonable to assume that having an understanding of the torture prevalent in a certain part of the world can minimize the risk of overlooking or misinterpreting signs of abuse. In addition, there is also the issue of under reporting, as for some victims it is extremely stressful to share their torture experience, especially in cases of sexual abuse. ${ }^{1,7}$ Therefore knowledge of the geographical patterns of different forms of torture is a valuable resource to the examiner, given it is necessary to establish a relationship of trust, understanding and empathy between the examiner and victim to minimize the risk of under reporting. ${ }^{1,10}$

\section{Materials}

This study includes 154 reports from examinations of alleged torture victims among asylum seekers conducted at the Department of Forensic Medicine at the University of Copenhagen from 1 January 2001 to 31 May 2013. The study is made up of the medical history of 146 males and eight females, and includes their description of the alleged torture. One case file did not include any geographical data of the torture victim and was excluded from the study. In all 154 reports it was concluded that the victim's description of torture was consistent with the findings of the physical examination.

\section{Categorization of torture victims according to geographical origin}

Every victim was registered according to the country where they were tortured. In almost all cases this was the same as their country of origin (see Table 1). These data were then filed under four categories encompassing larger geographical territories. The decision to separate the continent of Africa into two regions is based on cultural similarities between the countries of the Middle East and North Africa. The number of cases from each country is indicated in parentheses.

Half of the cases were from the Middle 
East, primarily Syria, Iran and Iraq, and one third from Asia, primarily India (see Table 1). The average age of the victims at the time of examination was comparable. In all groups the average age was close to 30 , with a range from 17 to 59 years.

Because of the small sample group of females, gender specific analyzes were not

Table 1: Torture victims grouped by geographical region (the number of victims from each country in parentheses)

\begin{tabular}{llll}
\hline Torture victims & No. of females & Mean age
\end{tabular}

Middle East 74

1

32.7

Syria (20)

Iran (18)

Iraq (14)

Lebanon (7)

Libya (7)

Turkey (4)

Algeria, Egypt, Palestinian

Territory (Occupied) (1 each)

Asia

India (25)

Sri Lanka (8)

Afghanistan (8)

Pakistan (6)

China (4)

Bangladesh, Vietnam (1 each)

Europe

Azerbaijan (5)

Russia (3)

Kosovo (2)

Armenia, Belarus, Bosnia, Croatia, Chechnya (1 each)

Sub-Saharan Africa

DR Congo (4)

Sudan (4)

Cameroon (2)

Burundi, Nigeria,

Uganda (1 each) 
carried out, except in the case of sexual torture, as this form of torture was heavily overrepresented among female torture survivors.

\section{Categorization of torture victims according to conflict}

The torture victims were furthermore categorized according to the conflict which the torture was allegedly related to (see Table 2). These categories are based on those established by Leth and Banner ${ }^{10}$ but have been altered to better fit the present data. There were 16 groups, including exclusion groups, i.e. torture cases not related to any specific, larger conflict. The total number of victims from each category is written in parentheses:

- Torture related to other/unknown reasons in the Middle East (27)

- Torture related to Hinduism-Sikhism relations in northwestern India and/or related to the Khalistan-movement (22)

- Torture related to Kurdish ethnicity, including victims from Turkey, Iraq and Syria (17)

- Political opposition in Iran (16)

- Political opposition in Sub-Saharan Africa (11)

- Political opposition in Iraq (10)

- Torture related to the Sri Lankan civil war (8)

- Torture related to the Israeli-Palestinian conflict (7)

- Political opposition in Afghanistan (7)

- Torture related to other/unknown reasons in Asia (7)

- Political opposition in Azerbaijan (6)

- Torture related to other/unknown reasons in Europe (5)

- Torture related to conflict in the Balkans (4)

- Political opposition in Pakistan (4)

- Torture related to other/unknown reasons in Sub-Saharan Africa (2)
Table 2: Victims grouped by conflict

\begin{tabular}{lccc}
\hline & Victims & $\begin{array}{c}\text { No. of } \\
\text { females }\end{array}$ & Mean age \\
\hline OME & 27 & 2 & 34,6 \\
S & 22 & 0 & 28,6 \\
K & 17 & 0 & 31,1 \\
PN & 16 & 0 & 31,2 \\
PS & 11 & 1 & 32,1 \\
PQ & 10 & 1 & 33,4 \\
SL & 8 & 1 & 28,6 \\
\hline
\end{tabular}

$\mathrm{OME}=$ Torture related to other/unknown reasons in the Middle East

$\mathrm{S}=$ Persecution related to Sikh-Hindu conflicts and/or the Khalistan Movement

$\mathrm{K}=$ Persecution related to Kurdish ethnicity

$\mathrm{PN}=$ Political opposition in Iran

PS = Political opposition in Sub-Saharan Africa

$\mathrm{PQ}=$ Political opposition in Iraq

SL $=$ Sri Lankan civil war

- Unspecified reason, unspecified country of origin (2)

Many of these categories represent a small number of examined victims and thus do not provide an accurate overview of the torture methods observed in these regions. For this reason only the seven categories, which include eight ( $5 \%$ of all cases) or more individuals have been included in the results (see Table 1).

One of the included groups, "Torture related to other/unknown reasons in the Middle East (OME)", needs further explanation, as it is a category encompassing a broad spectrum of victims. This category excludes the four other groups comprised of torture victims from the Middle East (i.e. cases related to political opposition in Iran or Iraq, to Kurdish ethnicity and to the Israeli-Palestinian conflict). Many of the victims included in the group "Middle East and North Africa" reported being tortured because of allegations of political opposition in Syria, Libya or Lebanon. 
Others were Iraqis/Iranians who were tortured for reasons other than their political affiliation.

\section{Methods}

Each case was categorized according to the victim's nationality and the conflict the torture was related to. The torture victim's statement about any inflicted torture was registered, and any recorded statements of torture were then grouped according to the categorization of torture methods in the Istanbul Protocol.

We did not distinguish between single and multiple events of the same form of torture. Some incidents were included in multiple categories. For example, the application of an electrical shock to the genitalia was registered as both "electric shock" and "sexual violence".

\section{Classification of torture methods}

Since torture encompasses many different forms of abuse, both psychological and physical, it is necessary to have a practical method of classification to adequately document it. This study bases its categorization on Chapter IV of the Istanbul Protocol ("Review of Torture Methods"), section G. While this system ensures there is a complete examination for all methods of torture, the division of torture methods into physical and psychological is artificial, ${ }^{7}$ as is also stated in the same chapter of the Protocol. Twelve of the Protocol's 21 categories were selected for this report, those in which at least $10 \%$ of the cases of torture from at least one geographical region were represented. For a closer description of these categories see Table 3.

Table 3: Description of the 12 categories of torture forms as defined in the Istanbul Protocol

1. Blunt trauma, such as hitting, kicking, slapping, whipping, beating with poles or trauma from falling

2. Positional torture including painful positions, possibly induced through suspension, and prolonged constraint of movement

3. Burns with cigarettes, heated instruments, scalding liquid or caustic substance

4. Electric shocks

5. Asphyxiation such as wet and dry methods, drowning, smothering, choking or use of chemicals

6. Crush injuries, such as smashing fingers or using a heavy roller to injure the thighs or back

7. Penetrating injuries, such as stab or gunshot wounds, wires under nails

8. Chemical exposure to salt, chili pepper, gasoline, etc. (in wounds or body cavities)

9. Sexual violence to genitals, molestation, instrumentation, rape

10. Pharmacological torture using toxic doses of sedatives, neuroleptics, paralytics, etc.

11. Conditions of detention, such as a small or overcrowded cell, solitary confinement, unhygienic conditions, no access to toilet facilities, irregular or contaminated food and water, exposure to extremes of temperature, denial of privacy and forced nakedness

12. Deprivation of normal sensory stimulation, such as sound, light, sense of time, isolation, manipulation of brightness of the cell, abuse of physiological needs, restriction of sleep, food, water, toilet facilities, bathing, motor activities, medical care, social contacts, isolation within prison, loss of contact with the outside world (victims are often kept in isolation in order to prevent bonding and mutual identification and to encourage traumatic bonding with the torturer 
Table 4: Number of torture cases reported, grouped according to region and type of torture (percentage of total from each region in italics)

\begin{tabular}{|c|c|c|c|c|c|c|c|c|c|c|c|c|c|}
\hline \multirow[b]{2}{*}{ A } & \multirow[b]{2}{*}{52} & \multicolumn{2}{|c|}{$\begin{array}{c}\text { Blunt } \\
\text { trauma }\end{array}$} & \multicolumn{2}{|c|}{$\begin{array}{l}\text { Pos. } \\
\text { torture }\end{array}$} & \multicolumn{2}{|c|}{ Burns } & \multicolumn{2}{|c|}{ Electricity } & \multicolumn{2}{|c|}{$\begin{array}{c}\text { Asphyx- } \\
\text { iation }\end{array}$} & \multicolumn{2}{|c|}{$\begin{array}{l}\text { Crush } \\
\text { injury }\end{array}$} \\
\hline & & 51 & 98 & 30 & 58 & 18 & 35 & 9 & 17 & 5 & 10 & 14 & 27 \\
\hline $\mathrm{E}$ & 15 & 14 & 93 & 5 & 33 & 6 & 40 & 2 & 13 & 2 & 13 & 0 & 0 \\
\hline $\mathrm{ME}$ & 74 & 74 & 100 & 53 & 72 & 25 & 34 & 23 & 31 & 6 & 8 & 0 & 0 \\
\hline SSA & 13 & 13 & 100 & 4 & 31 & 3 & 23 & 2 & 15 & 1 & 8 & 0 & 0 \\
\hline \multirow[t]{2}{*}{ Total } & 154 & 152 & 99 & 92 & 60 & 52 & 34 & 36 & 23 & 14 & 9 & 14 & 9 \\
\hline & & \multicolumn{2}{|c|}{$\begin{array}{l}\text { Sharp } \\
\text { trauma }\end{array}$} & \multicolumn{2}{|c|}{$\begin{array}{l}\text { Chem. } \\
\text { torture }\end{array}$} & \multicolumn{2}{|c|}{$\begin{array}{l}\text { Sexual } \\
\text { torture }\end{array}$} & \multicolumn{2}{|c|}{$\begin{array}{l}\text { Pharm. } \\
\text { torture }\end{array}$} & \multicolumn{2}{|c|}{$\begin{array}{c}\text { Poor } \\
\text { detention } \\
\text { conditions }\end{array}$} & \multicolumn{2}{|c|}{$\begin{array}{c}\text { Sensory } \\
\text { deprivation }\end{array}$} \\
\hline A & 52 & 10 & 19 & 13 & 25 & 12 & 23 & 0 & 0 & 6 & 12 & 12 & 23 \\
\hline $\mathrm{E}$ & 15 & 4 & 27 & 3 & 20 & 4 & 27 & 2 & 13 & 2 & 13 & 3 & 20 \\
\hline ME & 74 & 12 & 16 & 5 & 7 & 23 & 31 & 4 & 5 & 19 & 26 & 27 & 36 \\
\hline SSA & 13 & 5 & 38 & 1 & 8 & 4 & 31 & 1 & 8 & 5 & 38 & 2 & 15 \\
\hline Total & 154 & 31 & 20 & 22 & 14 & 43 & 28 & 7 & 5 & 32 & 21 & 44 & 29 \\
\hline
\end{tabular}

$\mathrm{A}=$ Asia incl. Pakistan and Afghanistan

$\mathrm{E}=$ Europe

As Table 4 illustrates, blunt trauma was by far the most reported form of torture, followed by positional torture. Burns, sexual torture and sensory deprivation were reported in over a quarter of all cases, whereas all other forms of torture were reported by less than one quarter of all victims. Major regional differences were especially apparent regarding electrical torture and crush injuries.

Categorization of victims according to conflict (see Table 5) revealed that blunt trauma and positional torture were among the most reported forms of torture. Group "Hinduism-Sikhism" victims were the only ones to report crush injuries; sharp trauma
$\mathrm{ME}=$ Middle East and North Africa $\mathrm{SSA}=$ Sub-Saharan Africa was reported by almost half of the group, twice the amount rate of any other group. In the group "Torture related to other/unknown reasons in the Middle East" there was a high number of reports of electrical torture, almost every second case. Burns and sexual torture were reported by between a quarter and a third of every victim in all groups.

Chemical torture was more frequently reported by victims from groups "Hinduism-Sikhism" and "Sri Lankan civil war", the only two East Asian groups included.

\section{Discussion}

Our findings indicate that violence using blunt force is prevalent in almost all torture 
Table 5: Distribution of torture forms grouped by conflict (percentage of total in each conflict category in italics)

\begin{tabular}{|c|c|c|c|c|c|c|c|c|c|c|c|c|c|}
\hline \multirow[b]{2}{*}{ OME } & \multirow[b]{2}{*}{26} & \multicolumn{2}{|c|}{$\begin{array}{l}\text { Blunt } \\
\text { trauma }\end{array}$} & \multicolumn{2}{|c|}{$\begin{array}{l}\text { Pos. } \\
\text { torture }\end{array}$} & \multicolumn{2}{|c|}{ Burns } & \multicolumn{2}{|c|}{ Electricity } & \multicolumn{2}{|c|}{$\begin{array}{c}\text { Asphyx- } \\
\text { iation }\end{array}$} & \multicolumn{2}{|c|}{$\begin{array}{l}\text { Crush } \\
\text { injury }\end{array}$} \\
\hline & & 26 & 100 & 21 & 81 & 10 & 38 & 12 & 46 & 3 & 12 & 0 & 0 \\
\hline$S$ & 22 & 22 & 100 & 16 & 73 & 7 & 32 & 4 & 18 & 2 & 9 & 13 & 59 \\
\hline $\mathrm{K}$ & 17 & 17 & 100 & 11 & 65 & 4 & 24 & 4 & 24 & 0 & 0 & 0 & 0 \\
\hline PN & 16 & 16 & 100 & 12 & 75 & 6 & 38 & 4 & 25 & 1 & 6 & 0 & 0 \\
\hline PS & 11 & 11 & 100 & 4 & 36 & 3 & 27 & 2 & 18 & 1 & 9 & 0 & 0 \\
\hline PQ & 10 & 10 & 100 & 5 & 50 & 3 & 30 & 2 & 20 & 1 & 10 & 0 & 0 \\
\hline SL & 8 & 8 & 100 & 6 & 75 & 4 & 50 & 1 & 13 & 2 & 25 & 0 & 0 \\
\hline \multirow[t]{2}{*}{ Total } & 110 & 110 & 100 & 75 & 68 & 37 & 34 & 29 & 26 & 10 & 9 & 13 & 12 \\
\hline & & \multicolumn{2}{|c|}{$\begin{array}{l}\text { Sharp } \\
\text { trauma }\end{array}$} & \multicolumn{2}{|c|}{$\begin{array}{l}\text { Chem. } \\
\text { torture }\end{array}$} & \multicolumn{2}{|c|}{$\begin{array}{c}\text { Sexual } \\
\text { torture }\end{array}$} & \multicolumn{2}{|c|}{$\begin{array}{l}\text { Pharm. } \\
\text { torture }\end{array}$} & \multicolumn{2}{|c|}{$\begin{array}{c}\text { Poor } \\
\text { detention } \\
\text { conditions }\end{array}$} & \multicolumn{2}{|c|}{$\begin{array}{c}\text { Sensory } \\
\text { deprivation }\end{array}$} \\
\hline OME & 26 & 4 & 15 & 0 & 0 & 10 & 38 & 1 & 4 & 6 & 23 & 6 & 23 \\
\hline S & 22 & 4 & 18 & 7 & 32 & 6 & 27 & 0 & 0 & 2 & 9 & 4 & 18 \\
\hline $\mathrm{K}$ & 17 & 0 & 0 & 0 & 0 & 4 & 24 & 2 & 12 & 4 & 24 & 6 & 35 \\
\hline PN & 16 & 3 & 19 & 3 & 19 & 4 & 25 & 1 & 6 & 3 & 19 & 10 & 63 \\
\hline PS & 11 & 5 & 45 & 1 & 9 & 3 & 27 & 1 & 9 & 4 & 36 & 1 & 9 \\
\hline PQ & 10 & 2 & 20 & 2 & 20 & 2 & 20 & 0 & 0 & 3 & 30 & 4 & 40 \\
\hline SL & 8 & 2 & 25 & 3 & 38 & 2 & 25 & 0 & 0 & 1 & 13 & 4 & 50 \\
\hline Total & 110 & 20 & 18 & 16 & 15 & 31 & 28 & 5 & 5 & 23 & 21 & 35 & 32 \\
\hline
\end{tabular}

$\mathrm{OME}=$ Torture related to other/unknown reasons in the Middle East

$\mathrm{S}=$ Torture related to Hinduism-Sikhism relations and/or the Khalistan-movement

$\mathrm{K}=$ Torture related to Kurdish ethnicity

cases, regardless of where the torture takes place. This is in accordance with findings of many previous studies, which generally describe an incidence of $95-100 \% .^{6-8,10-13}$

Some authors report a lower incidence of blunt force trauma against females. For instance, Masmas et al. ${ }^{3}$ reported an incidence of $78 \%$, whereas Edston and Olsson $^{12}$ found an incidence almost identical
$\mathrm{PN}=$ Torture related to political opposition in Iran PS = Torture related to political opposition in Sub-Saharan Africa $\mathrm{PQ}=$ Torture related to political opposition in Iraq SL $=$ Torture related to the Sri Lankan civil war

to the one found in tortured males. Our findings correlate with the latter. Keatley et al. found the prevalence of head injuries after torture to be $69 \%$ among 488 patients, mainly immigrants from Sub-Saharan Africa and Southeast Asia. ${ }^{14}$

The victims from Sub-Saharan Africa generally reported penetrating injuries more often than others, $42 \%$ compared to $27 \%$ in 
the second-highest group. They also reported bad detention conditions more often than other groups. These results correspond with those of Moisander and Edston, ${ }^{15}$ although they found a much higher incidence among victims from Bangladesh, where only one person in our study originated from. There were no reports of penetrating injuries among Kurdish victims, compared to Bradley and Tawfiq's findings of $14 \%{ }^{6}$

Positional torture was one of the most reported forms of torture, present in 58\% and $67 \%$ of the cases from Asia and the Middle East, respectively, and at least one third of all groups. Earlier studies have found rates ranging from $33 \%$ among Lebanese asylum applicants ${ }^{11}$ to $40 \%$ in Sikh asylum applicants. ${ }^{8} \mathrm{~A}$ lower incidence of $14 \%$ among Italian asylum seekers, mainly from Africa and the Middle East, was reported in a study by Di Napoli et al., which could indicate that positional torture is less prevalent among African victims than the rest of the world. ${ }^{16}$

Electrical torture was approximately twice as common among applicants from the Middle East (31\%) compared to other groups. The conflict analysis shows that it was primarily individuals that were not associated with political opposition in Iran or Iraq and/or were tortured because of Kurdish ethnicity. This correlates with Moisander and Edston, ${ }^{15}$ who reported a prevalence of $46 \%$ and $56 \%$ among applicants from Syria and Turkey, respectively, and $0 \%$ among Iranians. Hougen ${ }^{11}$ found an incidence of $25 \%$ among a sample of Lebanese asylum applicants and Rasmussen ${ }^{7}$ reported a much higher incidence $(63 \%)$ among tortured Iraqis. Leth and Banner ${ }^{10}$ found a general incidence of electrical torture of $31 \%$ in 2005 .

Crush injuries were only reported among individuals from Asia. All of theses cases were from Sri Lanka, aside from one from Pakistan. Moisander and Edston ${ }^{15}$ found a prevalence of $9 \%$ among Bangladeshi refugees and $0 \%$ among all other groups. Forrest ${ }^{8}$ found an incidence of $49 \%$ among Sikh asylum-seekers in 1995.

Burns were reported by a quarter to a third of all applicants. The proportion was lowest among Kurdish applicants (23\%). A similar prevalence $(18 \%)$ was found by Bradley and Tawfiq. ${ }^{6}$

Sexual torture was reported by $78 \%$ of the females $(66 \%$ of female cases reported rape) and $25 \%$ of the male applicants ( $8 \%$ of male cases reported rape). Analysis across regional groups was not feasible due to the low number of female cases, but the discrepancy between sexual torture among males and females is clear. These findings are similar to those of other studies. ${ }^{6,13}$ In 2007, Edston and Olsson ${ }^{12}$ found a prevalence of rape of $70 \%$ among female torture victims. Morof et al. reported a prevalence of sexual violence and rape of $63 \%$ and $49 \%$, respectively, among 117 Congolese and Somalian women in a study from $2014 .{ }^{17}$ The low number of female cases in general in this study mirrors the findings of Poole and Galpin, who reported only nine female cases in a sample of 144 torture survivors among New Zealand quota refugees. ${ }^{18}$

One important weakness of our study is that our data stems from a selected group of victims, namely those who were able to flee from persecution in their home country and travel to Denmark to seek asylum. There are a large number of victims who either never flee their home country or flee to other parts of the world. Therefore, our results give a superficial insight into the regional differences in torture practices in the world, and should not be used for general extrapolation.

We found that our results are generally 
comparable with other studies by European forensic institutes on the same subject, which suggests the findings are not entirely random.

It is important to look for all signs of torture during an examination, regardless of the nationality and history of the victim, even if certain types of injuries are known to be more probable based on nationality and ethnicity.

\section{Conclusion}

We found there is an uneven distribution of the alleged torture methods reported by asylum applicants in Denmark. Crush injuries were exclusively reported by Asian applicants and electrical torture was twice as commonly reported by applicants from the Middle East.

In general our findings mirror the prevalence of torture forms reported in previous studies; however, we reported a generally higher prevalence of positional torture, especially among refugees from the Middle East and Asia. A quarter of male cases reported sexual torture, which is higher than in most previous studies. This finding corroborates the notion that sexual torture is generally underreported among male torture survivors. ${ }^{19}$ The reason for the high rate of disclosure could be a high level of trust in the examining physicians. It is not possible to ascertain a more precise explanatory factor.

These findings provide information about the prevalence of certain forms of torture that can be a valuable tool for physicians while interviewing and examining torture victims and in the documentation of torture.

The weakness of our study is the data which consists of a selected group of mostly male refugees in Denmark, who were examined at the Department of Forensic Medicine in Copenhagen. Our findings cannot be directly extrapolated to other groups; however we have found that other studies among similar populations of asylum applicants in other countries generally find similar results. The low number of female cases could indicate that females generally report torture less frequently than males, either because of barriers (language, patriarchal culture, shame) or because they are more easily overlooked by medical investigators. 


\section{References}

1. UN Office of the High Commissioner for Human Rights (OHCHR). Manual on the Effective Investigation and Documentation of Torture and Other Cruel, Inhuman or Degrading Treatment or Punishment ('Istanbul Protocol'). New York: United Nations Publications; 2001.

2. Danmarks Statistik [Internet]. [cited 2012]. Available from: http://www.dst.dk

3. Masmas T, Møller E, Buhmannr C, Bunch V, Jensen J, Hansen T, et al. Asylum seekers in Denmark-a study of health status and grade of traumatization of newly arrived asylum seekers. Torture. 2008;18(2):77-86.

4. Forrest D. The physical after-effects of torture. Forensic Sci Int. Elsevier BV; 1995 Nov;76(1):77-84.

5. Hargreaves S. A body of evidence: torture among asylum seekers to the West. The Lancet. Elsevier BV; 2002 Mar;359(9308):793-4.

6. Bradley L, Tawfiq N. The physical and psychological effects of torture in Kurds seeking asylum in the United Kingdom. Torture. 2006;16(1):41-7.

7. Rasmussen O. Medical Aspects of Torture: Copenhagen University. Copenhagen. 1989.

8. Forrest D. Patterns of abuse in Sikh asylumseekers. The Lancet. Elsevier BV; 1995 Jan;345(8944):225-6.

9. Moreno A, Grodin MA. Torture and its neurological sequelae. Spinal Cord. Nature Publishing Group; 2002 May 2;40(5):213-23.

10. Leth P, Banner, J. Forensic Medical Examination of Refugees Who Claim to Have Been Tortured. Am J Forensic Med Pathol. 2005;26(2):125-30.

11. Hougen HP. Physical and psychological sequelae to torture. A controlled clinical study of exiled asylum applicants. Forensic Sci Int. Elsevier BV; 1988 Oct;39(1):5-11.
12. Edston E, Olsson C. Female victims of torture. J Forensic Leg Med. Elsevier BV; 2007 Aug;14(6):368-73.

13. Sanders J, Schuman MW, Marbella AM. The epidemiology of torture: A case series of 58 survivors of torture. Forensic Sci Int. Elsevier BV; 2009 Aug; 189(1-3):e1-7.

14. Keatley E, Ashman T, Im B, Rasmussen A. Self-Reported Head Injury Among Refugee Survivors of Torture. J Head Trauma Rehabil. Ovid Technologies (Wolters Kluwer Health); 2013;28(6):E8-13.

15. Moisander PA, Edston E. Torture and its sequel - a comparison between victims from six countries. Forensic Sci Int. Elsevier BV; 2003 Nov;137(2-3):133-40.

16. Napoli AD, Baglio G, Bracci C, Taviani A, Zerbino E, Romano V. Torture survivor asylum seekers in Italy: the experience of the humanitarian association "Doctors Against Torture". Annali Di Igiene; 2005;17(4):343-50.

17. Morof DF, Sami S, Mangeni M, Blanton C, Cardozo BL, Tomczyk B. A cross-sectional survey on gender-based violence and mental health among female urban refugees and asylum seekers in Kampala, Uganda. International Journal of Gynecology \& Obstetrics. Elsevier BV; 2014 Nov;127(2):138-43.

18. Poole GE, Galpin G. Prevalence of victims of torture in the health screening of quota refugees in New Zealand during 2007-2008 and implications for follow-up care. Journal of the New Zealand Medical Association. 2011;124(1338):1824.

19. Oosterhoff P, Zwanikken P, Ketting E. Sexual Torture of Men in Croatia and Other Conflict Situations: An Open Secret. Reprod Health Matters. Elsevier BV; 2004 May;12(23):68-77. 